\title{
Differentiated Instruction for Basic Reading Comprehension in Philippine Settings
}

\author{
Roberto Suson ${ }^{1, *}$, Christna Baratbate ${ }^{2}$, Wilfredo Anoos ${ }^{1}$, Eugenio Ermac ${ }^{1}$, Amelia Girly Aranas ${ }^{1}$, \\ Nolasco Malabago ${ }^{3}$, Narcisan Galamiton ${ }^{4}$, Dennis Capuyan ${ }^{1}$ \\ ${ }^{1}$ College of Education and Technology, Cebu Technological University, Philippines \\ ${ }^{2}$ Department of Education, Pinamungahan, Philippines \\ ${ }^{3}$ College of Technology, Cebu Technological University, Philippines \\ ${ }^{4}$ Department of Information and Communication, Cebu Technological University, Philippines
}

Received April 3, 2020; Revised June 13, 2020; Accepted August 26, 2020

\section{Cite This Paper in the following Citation Styles}

(a): [1] Roberto Suson, Christna Baratbate, Wilfredo Anoos, Eugenio Ermac, Amelia Girly Aranas, Nolasco Malabago, Narcisan Galamiton, Dennis Capuyan, "Differentiated Instruction for Basic Reading Comprehension in Philippine Settings," Universal Journal of Educational Research, Vol. 8, No. 9, pp. 3814 - 3824, 2020. DOI: 10.13189/ujer.2020.080904.

(b): Roberto Suson, Christna Baratbate, Wilfredo Anoos, Eugenio Ermac, Amelia Girly Aranas, Nolasco Malabago, Narcisan Galamiton, Dennis Capuyan (2020). Differentiated Instruction for Basic Reading Comprehension in Philippine Settings. Universal Journal of Educational Research, 8(9), 3814 - 3824. DOI: 10.13189/ujer.2020.080904.

Copyright $\mathrm{C} 2020$ by authors, all rights reserved. Authors agree that this article remains permanently open access under the terms of the Creative Commons Attribution License 4.0 International License

\begin{abstract}
Differentiated instruction has been a buzz word in Philippine education for many years. Educators utilize differentiated approach in teaching to maximize and meet the expected learning outcomes. Previous study pointed out that students vary in terms of learning style and understanding the concept. This study aims to identify the role of differentiated instruction in teaching reading and promoting comprehension in basic education. This paper looked at four differentiated instructional strategies for teaching guided reading: Noting details, sequencing events, getting the main idea and predicting outcomes. Moreover, it seeks to determine the multiple intelligence profile and the performance in reading comprehension of the students. It also determines whether a significant correlation exists between the profile and the performance of the students. Data were generated using adapted multiple intelligences inventory instruments and written passages, prescribed curriculum by the Department of Education. The data obtained were analyzed using weighted mean, standard deviation, and chi-square. The findings revealed that students learned from all aspects of intelligence they have, no matter what the situation is. This was so intriguing because it was known that every individual has different learning intelligence. Pedagogically, the findings recommended that educators need to innovate to help meet the needs of diverse learners,
\end{abstract}

enriched reading activities, and differentiated instructions must be integrated to strengthen learner competence in basic reading comprehension. The surprising finding is that, though students learn differently, there are also some learning contexts, which students shared with the same entity. Therefore, teachers must recognize that students have different versions of learning.

Keywords Basic Education, Differentiated Instruction, Reading Comprehension, Multiple Intelligences

\section{Introduction}

The ability to read and comprehend are essential skills for students to survive and understand how society works because most information are presented through text. Prior research shows that reading helps mental development (Van, 2009: Yaseen, 2013). Seminal contributions have been made by Ogbodo (2002), Bhan \& Gupta (2010), and Singh (2011) have done work on reading and it shows a promising effect on the overall development of the students, especially for their academic journey. A series of recent study has indicated that the ability to comprehend helps the academic performance of the students. Cimmiyotti 
(2013) stated that reading is fundamental at all levels of the educational system because all subjects in the course involve reading and this will lead to better academic performance. Nyarko et al. (2018) in their study shows that a positive relationship between reading proficiency and academic performance. Palani (2012) present findings shows that effective learning reflects the reading skills of the students. Moreover, when students take part in constant reading, it doesn't only improve their vocabulary but also contributes to their comprehension of concepts (Duru and Koklu, 2011), which are significant for understanding and overall performance in school. However, the educational system is challenged to produce effective readers. This hinders the schools to meet its goal to provide quality and well informed individual. A study conducted by Mule (2014) shows that inadequate English reading material, improper teaching methodology and insufficient English language development were causes of reading difficulties. Lerner (2000, p.389) reports that learners who get off to a poor start in reading rarely catch up; poor first grade readers are likely to continue to be poor readers. A number of studies in the area of reading, for example, conducted by Chall (1987), Dickinson and Neuman (2006), and Lerner (2000) point out difficulties learning to read in English when it's not a first language. One program that has been adopted as intervention is differentiated instruction.

Differentiated instruction is a "buzz word" in Philippine education for many years. Research has shown that different strategies are inconsistently implemented in many reading classrooms and are rarely used across the country (Archambault et al., 1993; Reis et al., 2004; Reis \& Purcell, 1993; Westberg et al., 1993). The requirement to differentiate instruction and curriculum has never been more apparent because the needs of academically talented students are increasingly less of a spotlight in heterogeneous classrooms. Subsequently, reading programs are built up by and large school divisions by every open and non-public school for the researchers to build up a respectable reading habit. Alongside the slogan "Reading Skills, Key to Learning," the ECARP (Each Kid a Peruser Program) and DEAR (Drop Everything and Read) were made which were intended to outfit understudies with vital perusing and composing aptitudes (Ocampo, 2018).

In differentiated instruction, teaching is anchored on the curriculum and on the student's learning needs. The learning goals are adjusted to the students' learning preference. A teacher who emphasizes creative and critical thinking and the application of learning uses several instructional formats and a variety of instructional strategies. Nevertheless, the learning goals remain the same for all students and the teachers emphasize mastery of content and the skills. Primarily, in differentiated instruction, the teachers' use whole class instruction and tends to employ similar instructional strategies from one lesson to another (Tomlinson, 2012).

Differentiated instruction isn't simple and easy. Most school rooms are stuffed with students, having different educational skills and flexibility levels will vary drastically. As academics attempt to satisfy every student's individual desire, differentiation is vital as a result of it's concerning giving additional opportunities to students to grow their highest potential (Westman, 2018).

The genuine test lies in a manner to differentiated curriculum and is connected with learning exercises while not expanding and propagating an activity hole between the adaptability of each understudy. In the event that separation is mistakenly interpreted as meaning that an instructor should hold lower desires for more vulnerable understudies and constantly set them simpler learning assignments, at that point the understudies can only fall a ton of and increasingly behind. The real challenge is to supply differentiated 'on-the-spot support' to individual students all through the activities to adjust them to associate with steady learning exercises and continue with the peer group. (Graham et al., 2015).

Essentially, differentiating instruction means "teaching creatively" or changing differently on how you deliver instruction, and practice occurs in schools to improve reading achievement of the students. Outward from conventional classroom practices differentiating instruction includes a lot of interactive collaborations that are information-sophisticated and student-centered. Following an entire category activity for introducing or quickly reviewing vocabulary or an idea or talent, students then add little study teams and/or to appointed peer partners (Gibson, 2009).

Differentiated instruction can be used in all levels and branches of knowledge, and it is key when instructing students to read and comprehend new words. Molding ideal classrooms to instruct a gathering with a couple of interferences is critical to the educator and student accomplishment. While a few accessible assets portray separating guidance and envoy the need for scholastic change, less assets offer reasonable strides for making it occurs in the classrooms. (Benjamin, 2002; Dodge, 2006; Evertson \& Weinstein, 2006; Marzano, 2003; Heacox, 2001; Marzano, Norford, Paynter, Pickering, \& Gaddy, 2001; Tomlinson \& Eidson, 2003; Thousand, Villa, \&Nevin, 2007 Tomlinson \&McTighe, 2006). Most of the analysis so far has centered on teaching skills or strategies that enhance reading performance and comprehension, significantly with students who are in danger of reading failure. However, differentiating instruction in tiny teams advantages all students at each grade level notwithstanding with the content area. The educator must guarantee that students will be able to read and comprehend what they have read. (Fisher \& Frey, 2008; Denton, Bryan, Wexler, Reed, \& Vaughn, 2007; Vaughn et al, 2003; Foorman \& Torgesen, 2001).

In like manner, the ultimate goal of differentiation of instruction is to recognize the characteristics and meet the students learning style, to provide them with the challenges 
to develop their innate capability and further develop their skills (Linn-Cohen \& Hertzog, 2007). As an educator, one must demand on changes that will benefit all students. To validate the impact of differentiated education on student's performance, this present study will closely have a look at classroom practices that assist differentiation to determine if differentiated educational strategies have an effect of the basic reading comprehension of the students.

\section{Literature Review}

This study assumed the assessment of differentiated instruction for basic reading comprehension through enhanced reading activities. This contention depends on two speculations, to be specific: Lev Semonovich Vygotsky's Social Constructivist Hypothesis and Howard E. Gardner's Different Insights. Different Hypothesis centers around drawing in the students in their learning and permitting them to assume more noteworthy liability and responsibility for they exhibit their insight. This hypothesis clarify how an individual sees the world through every one of their particular insights. Finally, differentiated teaching is a way of approaching a range of learners and avoiding the pitfalls of a one-size-fits-all program that integrates existing research into human brain functions (Sousa \& Tomlinson 2011). Teachers selecting separation find that they can utilize time and assets adaptable and imaginatively, helping to make an air of joint effort in the classroom. To really sweeten the deal, separation can be drawn in understanding for educators as it includes an alternate sort of vitality contrasted with direct guidance.

\subsection{Reading}

Reading is the ability to understand words contained in a document and make use of the knowledge for personal growth and development (Dadzie, 2008). This implies making meaning out of recorded information either printed or non-printed in the life of an individual. People read for different reasons and purposes, some of which include for pleasure, leisure, relaxation, information and for knowledge. Palani (2012) believes that reading is a technique of thinking, evaluating, judging, imagining, reasoning and problem solving. Issa et al (2012) elaborates that via reading, the character is capable to build or fix things, experience stories, find out what others trust and boost ideas or beliefs of their own. Hence, reading provides the key to all types of information essential for our daily survival and growth. Moreover, a recent study by Sari (2017) concluded that reading is very important and helpful to us, not just in English class, but other subjects, such as mathematics, etc. also we need literacy skills to add to our knowledge of the material that we learned. Because reading, we can access a lot of information. It is argued that when reading skills are insufficient, a number of problems occur which lead to frustration in learning (Callahan \& Clark, 1988; Bender et al., 2008). Research has demonstrated the importance of reading skill for both comprehension (e.g., Voss \& Silfies, 1996) and academic achievement (e.g., Alcock et al., 2000). Experts claimed that both academic processes, particularly reading comprehension, share cognitive processes, such as predicting outcomes and sequencing events (Kumar \& Bristor, 1999). Particularly in noting details and getting the main idea Bowers (2000). Likewise, Belen et al. (2003) also stated that reading comprehension need to be the fundamental consideration of all readers. The ability of readers to recognize what they are reading; to interpret ideas and inject meaning into printed words incomprehension. To be able to apply different thought processes, the readers should know how to integrate words as part of the paragraph and paragraphs as part of the selection. They further added that reading is a complex process, thus it cannot be taught in isolation. Acquiring reading abilities is dependent upon the mastery of a broad range of reading competencies such as the following stages or dimensions of comprehension:

Table 1. Reading skills and dimension of Comprehensions

\begin{tabular}{cll}
\hline Reading skill & Level & Dimensions of Comprehension \\
\hline Noting Details & Literal & $\begin{array}{l}\text { When applied to the contents of a textbook, produces knowledge of what the author said. As } \\
\text { a reader, you decode words, determine what each word means in a given context and } \\
\text { recognize that there is some relationship between words which represents what the author } \\
\text { has said. Under this level, questions start with WHO, WHAT, WHERE and WHEN }\end{array}$ \\
\hline Sequencing Events & $\begin{array}{l}\text { Reading between the lines is applied to what the author said to derive meaning from a } \\
\text { statement. You look for relationships among statements within the material you have read. } \\
\text { Interpretative }\end{array}$ & $\begin{array}{l}\text { From these intrinsic relationships, you derive various meanings. HOW and WHY questions } \\
\text { are often asked that call for some reasoning, implications, conclusions assumptions and } \\
\text { interpretation provided for reading the selection. }\end{array}$ \\
\hline Predicting Outcomes & Applied & $\begin{array}{l}\text { Comprehension refers to what the author said and what the author meant by what he/she said } \\
\text { and applies it in some practical or theoretical exercise. }\end{array}$ \\
\hline Critical & $\begin{array}{l}\text { Comprehension refers to reading beyond the lines. As a reader, you give your reaction, } \\
\text { judgment, and evaluation of what is written. This involves how the the reader can distinguish } \\
\text { the literal meaning of words from suggestions or intentions expressed in the selection }\end{array}$ \\
\hline
\end{tabular}


Different studies which dealt with reading comprehension skills address the importance of different strategies that are exposed to develop the reading comprehension of the students. As perceived, noting details, sequencing events, getting the main ideas and predicting outcomes have a significant relationship in the development of being an effective reader (De Peralta,2014: Agsano, 2016: Yabes, 2016). See Table 1 for a description of each skills align to the dimension of comprehension.

\subsection{Reading Comprehension}

The importance of understanding the character of effective reading instruction within the primary grades can't be overstated (Ankrum, Genest, \& Morewood, 2017). This study is required to assist teachers that don't have the background or training and have to access and implement research-based reading instruction. The capacity to read and comprehend text is connected day by day, however, when it connects to the educational setting, it has more prominent significance, it leads to education for life since it impacts connections to the overall personality of the reader. In this manner, it is significant and important for the learners to build up the deciphering capacity, likewise having the option to become a competent and skill reader too. Thus, the reading process really occurs when there is reading comprehension. It is a highly important skill as a complex process which includes various cognitive and linguistic aspects (Cunha and Capellin, 2016).

One of the most fundamental comprehension talents is the capacity to locate the principle idea or principal notion of what one reads that allows you to pick the most vital idea of a mass of phrases, calls for a potential to distinguish between essentials and nonessentials, among the maximum critical idea and subordinate details or illustrations. Consequently, in view of (Harris and Sipay et. al.), major idea, inference ability enables freshmen to examine proficiently, properly and with knowledge whilst interacting with textual content. Moreover, in view of Yigiter, Saricoban and Gurses (2005) "language teachers must beautify students" capability to read with comprehension without comprehension, analyzing could be empty and meaningless" (p.124). Methods for differentiating curriculum and instruction in reading do exist. Some research supports the effectiveness of specific instructional and curricular strategies for use with readers who read several grades above or below grade level. For example, the use of instructional level grouping with differentiated content has been successful with talented readers, resulting in increased understanding and enjoyment of literature (Gentry, 1999; Levande, 1999). Research on instructional grouping with differentiated content has repeatedly been found to result in increased achievement for students across many different levels of reading ability (Gentry \& Owen, 1999; Kulik, 1992; Rogers, 1991; Tieso, 2002). Experts in reading agree that there is no best method to teach reading (Lerner, 2000;
Snow et al., 1998, Goodman, (1990). There are a number of different teaching methods from which teachers can choose. However, the question of which is the most effective continues to concern teachers. Understanding theories which explain the nature of learning to read could be used as the basis for improving the techniques of teaching reading to learners. In this study, the authors would like to find out if there is a correlation between the multiple intelligences of the students in relation to the above reading skills.

\subsection{Multiple Intelligences and Reading Comprehension}

Multiple Intelligence Theory (MI theory) outlined by Howard Gardner is a common theory that is not just applied to literacy. Instead the MI theory can be used across the curriculum to engage, teach and assess learning in many areas. MI theory is defined as eight and possibly even nine different intelligences' that are not defined by the simple IQ test, but instead "each person possesses all eight [or nine intelligences" (Armstrong, 2009). Howard Gardner has developed these and labelled them as: Linguistic, logical -mathematical, spatial, bodily kinesthetic, musical. Interpersonal, Intrapersonal, naturalistic. Gardner (1983) characterizes linguistics knowledge as the capacity to utilize language as an approach to know the request and furthermore the importance of words. Logical/mathematical intelligence requires the adaptability to compute and comprehend the different examples or reasons in an extremely efficient and intelligent way. It is related with numerical and logical reasoning. Visual/spatial insight includes the capacity to know, think and make mental pictures, shapes, examples, and plans so as to tackle issues. Musical intelligence incorporates the ability to make and perceive music, sing and to comprehend or utilize musicality. Sound-related capacities and acknowledgment of tonal and cadenced examples are required for a person to build up this insight. Music savvy remembers thinking for sounds and examples, performing music and driving into melodies. Artists, vocalists, voice mentors, and writers display melodic knowledge (Armstrong, 1994). Bodily/kinesthetic is that the capacity to utilize one's body abilities to take care of issues. It challenges and negates the conviction that psychological and physical exercises are irrelevant. Interpersonal intelligence includes people utilizing their social abilities to know and see individuals' inspirations, demeanors and objectives. It includes coordinating and speaking with others. Ordinary jobs are specialists, pioneers, instructors, educators, specialists and mentors (Gardner, 1993). Intrapersonal knowledge is that the capacity to separate, reflect, examine and recognize different individual musings and emotions and to utilize them to know and plan one's own conduct. Mindfulness, individual objectivity, and one's relationship to other people and the world are significant during this insight. 
Naturalist intelligence shows compassion, acknowledgment, and comprehension of living and regular things. It permits people to separate, group and use highlights of the untamed life around them. Average jobs are ranchers, geologists and plant specialists who can name and depict the highlights of the earth (Gardner, 1999).

There is a lot of research that disagrees with the notion of using MI Theory to increase reading comprehension such as that of researchers Heidari and Khorasaniha (2013) who noted 'concerning the relationship between MI and reading proficiency. A positive relationship was observed between reading scores and visual intelligence. However, among the nine intelligence profiles, however the visible intelligence made the best contribution to students' studying proficiency. This is due to the validity of the research and that there are too many variables to prove that it was only MI Theory that contributed to reading proficiency. On a good note though, I am a firm believer of using MI Theory to engage students and provide every student the best chance to succeed.

Gaines and Lehman (2002) mentioned that the use of MI principle to accelerate learners' reading comprehension and enhance their academic performance. Previous research conducted by Owolabi and Okebukola (2009) confirmed that reading comprehension in MI classrooms enhances learners' interaction with the print and thoughts presented. Abdulkader, Gundogdu and Eissa (2009), the implementation of MI theory coupled with expanded parental involvement can lead to large gains in the learners' reading comprehension and vocabulary knowledge. Moreover, Motallebzadeh and Manuchehri (2008), focusing on the relationship between MI and reading comprehension of learners, hold that MI idea can improve learners' studying skill, specifically through logical intelligence. Akbari and Hosseini (2008) sought to decide the relationship between the use of language learning techniques and MI scores. Significant relationships have been observed between them. Similarly, Razmjoo (2008) investigated the relationship between MI and English language proficiency in Iran. He concluded that there is no significant relationship between MI and language proficiency in the Iranian context.

Moreover, Tomlinson (1995) highlights that when teachers differentiate the curriculum, their roles become different from fountain of knowledge to facilitator and organizer of learning opportunities. In addition, differentiated instruction in reading requires that teachers assess students' current levels of reading achievement and match reading content and instruction to the needs of students to enable all students to make continuous progress. Many different methods exist to differentiate reading instruction (Firmender, 2013).

\section{Research Objectives}

In this study, the researchers attempt to examine the relationship between multiple intelligences (MI) as predictor of reading comprehension of the students. Thus, the study seeks to answer the following objectives:

i. To determine the multiple intelligences (MI) used by the students as predictors of reading comprehension.

ii. To assess the level of reading skills of the students.

iii. To determine whether a significant correlation exists between MI and reading skills of the students.

\section{Methodology}

This study applies a descriptive-normative method of research to assess the reading comprehension of the students using differentiated instructions. According to Shields and Rangarajan (2013), descriptive research is used to describe characteristics of a population being studied. It does not describe what caused a situation. The technique was that was used under descriptive method is a survey approach which is normally used to explore opinions according to respondents that can represent a whole population. The survey is appropriate in this study because it enables the researcher in the formulation of generalizations. This study was carried out in the province of Cebu, Philippines, under Department of Education. In this study, simple random sampling has been utilized to determine the population samples. 352 students had been randomly selected as the samples of the study.

This study used two research instruments. The content was mainly prepared according to the K-12 BEC (Basic Education Curriculum) learning competency. The first instrument is an adopted multiple intelligences inventory checklist. The content on the checklists was used to test the strength and weaknesses of the students in terms of different intelligences as to: linguistic, logical-mathematical, spatial, bodily-kinesthetic, musical, interpersonal, intrapersonal and naturalistic intelligence. The second instrument was a teacher who made questionnaire based on the written passages of the grade 4 curriculum prescribed by the Department of Education.

The content of the items was used to test the reading skills performance in reading comprehension as to: Noting details, sequencing events, getting the main idea and predicting outcomes. This was validated by the statistician and was pilot tested. Ethical procedure was carried off before the questionnaires were administered, the researchers asked permissions from the district supervision through the school principal. After the research questionnaires were accomplished, they were collated and the data tabulated and statically treated with the aid of statistical software, then analyzed and interpreted as to their significance to the study. Mean was used to determine the central tendency of the performance and the standard deviation. While chi-square test of independence for the 
significant correlation. During the actual gathering of the data, the researcher ensured that the respondents were doing their honest and sincere responses as they were assured of the confidentiality of their identity and responses. The researcher also ensured that there was no outside influence on the way the respondents give their responses; hence the researcher did not allow those who are not respondents to be present during the actual data gathering.

\section{Findings}

Table 2. Multiple Intelligences Profile of the Respondents

\begin{tabular}{|c|c|c|}
\hline Multiple Intelligences & Mean & Standard Deviation \\
\hline Linguistics & 3.05 & 0.41 \\
\hline Logical Mathematical & 3.07 & 0.12 \\
\hline Spatial & 3.48 & 0.24 \\
\hline Bodily Kinesthetic & 3.04 & 0.26 \\
\hline Musical & 3.08 & 0.25 \\
\hline Interpersonal & 3.12 & 0.32 \\
\hline Intrapersonal & 3.09 & 0.16 \\
\hline Naturalistic & 3.04 & 0.22 \\
\hline
\end{tabular}

This finding in table 2 implies that most learners have varied ways of recognizing strengths and weaknesses in each of the intelligences. With regards to the profile of the students Spatial intelligences was dominant with the mean of 3.48, (SD) of 0.24 , followed by interpersonal intelligences with a mean of 3.12 , (SD) of 0.32 . While Naturalistic intelligences got the lowest mean of 3.04, (SD) of 0.22 . As referred to by Eisner (2004) every other variable to preserve in idea is that the implementation of MI in the school room makes it tougher to compare pupil achievement levels in terms of students, classrooms, schools, and school districts (p. 33). This is due to the fact that there is now not one constant measuring device for assessment. One teacher may additionally use a number of one-of-a-kind assessments inside their own classroom, which may be distinctive from the assessments used by the other teachers teaching the same material for the equal grade level.

Table 3. Performance of the Respondents in Reading Comprehension

\begin{tabular}{|c|c|c|}
\hline Competencies & Mean & Standard Deviation \\
\hline Noting Details & 4.61 & 1.92 \\
\hline Sequencing Events & 6.74 & 3.28 \\
\hline Getting the Main Idea & 7.24 & 2.90 \\
\hline Predicting outcomes & 5.00 & 3.32 \\
\hline
\end{tabular}

Findings show that the performance of the learners in getting the main ideas got the highest mean of 7.24, (SD) of 2.90 which described as proficient, followed by sequencing events with a mean of 6.74 , (SD) 3.28 , predicting outcomes with a mean of 5.00, (SD) of 3.32 and noting details as the least got 4.62, (SD) of 1.92 which described as approaching to proficient. This shows that learners capability to adopt and learn new knowledge varies from activities that coordinate in their intelligence.

Findings show that bodily-kinesthetic intelligence as one of the multiple intelligences of the learners against sequencing events as skills, performance of the learners in reading comprehension warrants for the rejection of the null hypothesis at .05 level two-tailed test, thus, there is a significant correlation. This finding implies that the learners recognized sequencing events better with the use of their bodily-kinesthetic intelligence. Similarly, permits to reject the null hypothesis at .05 level two-tailed test, thus, significant interpersonal intelligence against sequencing events also correlation exists. This finding implies that the learners would learn better the art of sequencing events if they are intrinsically motivated. Other multiple intelligences against skills in performance in reading comprehension failed to reject the null hypothesis hence, no significant correlation exists. 
Table 4. Significant Correlation between the Multiple Intelligence Profile and the Performance of the Learners

\begin{tabular}{|c|c|c|c|c|}
\hline Competencies & $\begin{array}{c}\text { Degrees of } \\
\text { Freedom }\end{array}$ & $\begin{array}{c}\text { Chi-Square Test of } \\
\text { Independence }\end{array}$ & Ho & $\begin{array}{l}\text { P-value Level } \\
\text { of Significance }\end{array}$ \\
\hline Linguistic \& Noting details & 16 & $0.294934>0.05$ & Do not Reject Ho & No Significance \\
\hline Linguistic \& Sequencing Events & 16 & $0.6604027>0.05$ & Do not Reject Ho & No Significance \\
\hline Linguistic \& Getting the Main Idea & 16 & $0.371519384>0.05$ & Do not Reject Ho & No Significance \\
\hline Linguistics \& Predicting Outcomes & 16 & $0.189760418>0.05$ & Do not Reject Ho & No Significance \\
\hline Logical-Mathematical \& Noting Details & 16 & $0.119043>0.05$ & Do not Reject Ho & No Significance \\
\hline Logical- Mathematical \& Sequencing Events & 16 & $0.126174827>0.05$ & Do not Reject Ho & No Significance \\
\hline Logical- Mathematical \& Getting the Main Idea & 16 & $0.669134573>0.05$ & Do not Reject Ho & No Significance \\
\hline Logical-Mathematical \& Predicting Outcomes & 16 & $0.559492836>0.05$ & Do not Reject Ho & No Significance \\
\hline Spatial \& Noting Details & 16 & $0.395286>0.05$ & Do not Reject Ho & No Significance \\
\hline Spatial Intelligence \& Sequencing Events & 16 & $0.795026333>0.05$ & Do not Reject Ho & No Significance \\
\hline Spatial Intelligence \& Getting the Main Idea & 16 & $0.663540567>0.05$ & Do not Reject Ho & No Significance \\
\hline Spatial Intelligence \& Predicting Outcomes & 16 & $0.346778418>0.05$ & Do not Reject Ho & No Significance \\
\hline Bodily-Kinesthetic \& Noting Details & 16 & $0.789215193>0.05$ & Do not Reject Ho & No Significance \\
\hline Bodily-Kinesthetic \& Sequencing Events & 16 & $0.042131612<0.05$ & Do not Reject Ho & No Significance \\
\hline Bodily-Kinesthetic \& Getting the Main Idea & 16 & $0.561085216>0.05$ & Do not Reject Ho & No Significance \\
\hline Bodily-Kinesthetic \& Predicting Outcomes & 16 & $0.244487921>0.05$ & Do not Reject Ho & No Significance \\
\hline Musical Intelligence \& Noting Details & 16 & $0.645638991>0.05$ & Do not Reject Ho & No Significance \\
\hline Musical Intelligence \& Sequencing Events & 16 & $0.193432565>0.05$ & Do not Reject Ho & No Significance \\
\hline Musical Intelligence \& Getting the Main Idea & 16 & $0.067175294>0.05$ & Do not Reject Ho & No Significance \\
\hline Musical Intelligence \& Predicting Outcomes & 16 & $0.202878106>0.05$ & Do not Reject Ho & No Significance \\
\hline Interpersonal Intelligence \& Noting Details & 16 & $0.144139883>0.05$ & Do not Reject Ho & No Significance \\
\hline Interpersonal Intelligence \& Sequencing Events & 16 & $0.069308652>0.05$ & Reject Ho & Significance \\
\hline Interpersonal Intelligence \& Getting the Main Idea & 16 & $0.837345952>0.05$ & Do not Reject Ho & No Significance \\
\hline Interpersonal Intelligence \& Predicting Outcomes & 16 & $0.202878106>0.05$ & Do not Reject Ho & No Significance \\
\hline Intrapersonal Intelligence \& Noting Details & 16 & $0.494452792>0.05$ & Do not Reject Ho & No Significance \\
\hline Intrapersonal Intelligence \& Sequencing Events & 16 & $0.039120176<0.05$ & Do not Reject Ho & No Significance \\
\hline Intrapersonal Intelligence $\&$ Getting the Main Idea & 16 & $0.069099793>0.05$ & Do not Reject Ho & No Significance \\
\hline Intrapersonal Intelligence \& Predicting Outcomes & 16 & $0.298482739>0.05$ & Do not Reject Ho & No Significance \\
\hline Naturalistic Intelligence \& Noting Details & 16 & $0.541134565>0.05$ & Do not Reject Ho & No Significance \\
\hline Naturalistic Intelligence \& Sequencing Events & 16 & $0.249233169>0.05$ & Do not Reject Ho & No Significance \\
\hline Naturalistic Intelligence \& Getting the Main Idea & 16 & $0.892731141>0.05$ & Do not Reject Ho & No Significance \\
\hline Naturalistic Intelligence \& Predicting Outcomes & 16 & $0.820975773>0.05$ & Do not Reject Ho & No Significance \\
\hline
\end{tabular}

\section{Discussion}

In this study, the researchers attempt to examine the relationship between multiple intelligences (MI) as predictor of reading comprehension of the students and whether significant correlations exist between MI and reading skills. The first research question attempted to see which types of multiple intelligences is/are predictors of reading comprehension. Table 2 summarizes the descriptive data for the reading scores as well as the level of intelligences of the students. Our findings revealed out of 9 MI, spatial intelligence is dominant predictor of reading comprehension while naturalistic intelligence and bodily kinesthetic were the least. This finding is also consistent with the results of Busch and Gabrieli, and Norton (2012) found that the single best predictor of reading comprehension was the ability to recognize letters and sounds and the smallest contribution to the model was from visual motor intelligence. Similarly, Santi et al. (2015) who reported that visual motor integration influence the reading and language specific skills of the students when introduced. Several scholars (Turkeltaub et al. 2003: Vidyasagar, T.R and Pammer, K. 2010) have agreed that spatial intelligence has significant importance to reading comprehension. However, in contrast, Margolese et al.13 studied the impact of visual motor skills within the context 
of other language-based predictors of reading, including phonological skills and language comprehension. Results indicated that the strongest predictor of early reading was phonological skills. No effect of visual-motor skills was found when the phonological and language-based measures were included as predictors. Furthermore, previous study shows that a variety of intelligences emerged as significant predictor of reading comprehension. Zerie (2014) in his study figured out that musical intelligence was the best predictor of reading comprehension and vocabulary. While Hashemi (2007), found out that verbal intelligence make a significant contribution to predicting reading comprehension. This study revealed that some MI types could be predictors of reading comprehension.

While, Table 3 shows the extent of the reading skills of the students as to noting details, sequencing events, getting the main ideas and predicting outcomes. As for these reading skills, noting details and predicting outcomes were both excellent. While the other two were both proficient. It also observed that reading comprehension of pupils was significantly related with study hours at home, making inferences and exposure to mass media, and getting the main idea skills with materials read at home. However, the level of reading comprehension skills of students along predicting outcomes and sequencing events led no relationship with the pupils-related factors Yabes (2016). Table 3, on the other hand, shows that intrapersonal \& Sequencing Events is significantly correlated. These new findings may provide a framework for appreciating this intelligence as predictor of reading comprehension. This shared the results of Mirzaei et al. (2013) who figured out that intrapersonal has a significant positive relationship in reading comprehension.

\section{Conclusions}

The broader implication of the present research is that learners have diverse behaviors in confronting multiple intelligences. More precisely, the results have shown that no significant differences emerged with the multiple intelligences and reading skills of the students. However, intrapersonal and sequencing events are found to be significant. The data provide a further investigation as to what aspect that this competency different from the other. Overall, the results confirmed our hypothesis according to students who benefited from differentiated instruction developed reading comprehension. Our data indicate that differentiated instruction in the classroom provided a good result toward reading comprehension. From this perspective, our results are in line with other empirical studies revealing that students with different learning styles achieve better academic scores when the teaching strategies address their learning preferences (Tuburle, 2011;Beck, 2001; Felder \& Brent, 2005; Ford and Chen,
2001; Rogers, 2009; Shaugnessy, 1998). This conclusion follows from the fact that teachers must recognize that learners at school do not have similar attitudes and abilities in coping up from their class. Teachers need to provide more activities and learning techniques through differentiated instruction for the learners to enhance their reading comprehension skills no matter what intelligences they have. Finally, differentiated instruction is essential in basic reading comprehension. It creates a decisive and considerable benefit to struggling learners and that it recognizes not only the strengths and differences, but also the growing variety in the present classroom.

\section{REFERENCES}

[1] Ankrum, J.W., Genest, M.T., \& Morewood, A.L. (2017). A description of contrasting discourse patterns used in differentiated reading instruction. The Journal of Research in Childhood Education 31(3), 313-323.

[2] Armstrong, T. 2018. Multiple Intelligences in the Classroom $4^{\text {th }}$ ed. Alexandria, VA: Association for Supervision iiand Curriculum Development.

[3] Azizullah Mirzaei, Masoud Rahimi Domakani \& Najmeh Heidari (2014) Exploring the relationship between reading strategy use and multiple intelligences among successful L2 readers, Educational Psychology, 34:2, 208-230, DOI: $10.1080 / 01443410.2013 .785053$

[4] Abdulkader, F., Gundogdu, K., \& Eissa, M. (2009). The effectiveness of Multiple Intelligences-based program on improving certain reading skills in 5th-year primary learning disabled students. Electronic Journal of Research in Educational Psychology, 7(3), pp. 673-690.

[5] Agsano, K. (2016). Reading performance of the Grade IV pupils in La Paz District, Division of Abra. Unpublished master's thesis, University of Northern Philippines, Vigan City.

[6] Akbari, R., \& Hosseini, K. (2008). Multiple intelligences and language learning strategies: Investigating possible relations. System, 36(2), pp. 141-155.

[7] Armstrong, T. (2009). Multiple Intelligences in the Classroom (3rd ed.). USA: ASCD Publications.

[8] Bhan, K. S., \& Gupta, R. (2010) Study Habits and Academic Achievement among the students belonging to scheduled caste and non scheduled caste group. Journal of Applied Research in Education 15(1) pp. 1-9

[9] Bender, W., Boon, R., Fore III, C., Spencer, V., \& Stone, R. (2008). Use of text maps to improve the reading comprehension skills among students in high school with emotional and behavioral disorders. Tempe, 33(2), 87-98.

[10] Bowers, P. (2000). Reading and writing in the science classroom. Retrieved from http://www.eduplace.com/Scien ce/profdev/articles/ bowers.html

[11] Busch RF. Predicting first-grade reading achievement. Learn Disability Q 1980;3:38Y48 
[12] Beck, C. R. (2001). Matching teaching strategies to learning style preferences. The Teacher Educator, 37 (1), 1-15.

[13] Benjamin, A. (2002). Differentiated instruction: A guide for middle and high school teachers. Larchmont, NY: Eyes on Education.

[14] Callahan, J. \& Clark, L. (1988). Teaching in the middle and secondary schools: Planning for competence (3rd ed.). New York: Macmillan Publishing Company.

[15] Cimmiyotti, C. B. (2013). Impact of reading ability on academic performance at the primary level (Master's theses and Capstone projects. Paper 127). Dominican University, River Forest, IL.

[16] Chall, J. (1987). Stages of Reading Development. New York: McGraw-Hill

[17] Cunha and Capellini. 2016. Characterization of reading comprehension performance of students from 3rd to 5th grades of elementary. school.

[18] Dickinson, D. K. \& Neuman, S. B. (2006). Handbook of Early Literacy Research. Vol.2. New York: The Guilford Press.

[19] Dodge, J. (2006). Differentiation in action: A complete resource with research supported strategies to help you plan an organize differentiated instruction - and achieve success with all learners. New York: Scholastic

[20] Denton, C., Bryan, D., Wexler, J., Reed, D., \& Vaughn, S. (2007). Effective instruction for middle school students with reading difficulties: The reading teacher's sourcebook. Austin, TX: University of Texas System/Texas Education Agency.

[21] De Guzman, F. N. R. (2011). Reading comprehension ability of the Grade III pupils in the Laboratory Grade School, University of Northern Philippines, Unpublished master's thesis, University of Northern Philippines, Vigan City.

[22] Eisner, E. (2004). Multiple intelligences: Its tensions and possibilities. Teachers College Record, 106(1),31-39. 10.11111j.1467-9620.2004.00315.x

[23] Evertson\& C. S. Weinstein (Eds). 2006. Handbook of classroom management: Research, practice, and contemporary issues (pp. 3-16). Mahwah, NJ: Lawrence Erlbaum Associates.

[24] Frey, N., Fisher, D., \& Everlove, S. (2009). Productive group work: How to engage students, build teamwork, and promote understanding. Alexandria, VA: Association for Supervision and Curriculum Development.

[25] Felder, R. M., \& Brent, R. (2005). Understanding student differences. Journal of Engineering Education, 94 (1), 57-72.

[26] Ford, N., \& Chen, S. Y. (2001). Matching/ mismatching revisited: an empirical study of learning and teaching styles. British Journal of Educational Technology, 32 (1), 5-22.

[27] Foorman, B. R., \& Torgesen, J. (2001). Critical elements of classroom and small group instruction promote reading success in all children. Learning Disabilities: Research and Practice, 16(4), 203-212.

[28] Firmender, J. M., Reis, S. M., \& Sweeny, S. M. (2013).
Reading Comprehension and Fluency Levels Ranges Across Diverse Classrooms: The Need for Differentiated Reading Instruction and Content. Gifted Child Quarterly, 57(1), 3-14. https://doi.org/10.1177/0016986212460084

[29] Finding Specific Details in a Reading Selection. (2015, April 10). Retrieved fromhttps://study.com/academy/lesson/findin g-specific-details-in-a-reading-selection.html.

[30] Gardner, H. 2012. Multiple Intelligences; New Horizons. New York, NY. Basic Books. Print.

[31] Gibson, V. 2011. Differentiating Instruction: Teaching Differently to Improve Reading Instruction. Published by Read Naturally, Inc.

[32] Gibson, V., \& Hasbrouck, J. (2009). Differentiating instruction: Guidelines for implementation: Training manual. Wellesley Hills, MA: Gibson Hasbrouck \& Associates.

[33] Guignon, A (2004, November). Multiple intelligences: a theory for everyone. Retrieved February 18, 2008, from Education World Web site.

[34] Gentry, M. (1999). Promoting student achievement and exemplary classroom practices through cluster grouping: A research based alternative to heterogeneous elementary classrooms (RM 99138). Storrs: University of Connecticut, The National Research Center on the Gifted and Talented.

[35] Gaines, D., \& Lehmann, D. (2002). Improving student performance in reading comprehension through the use of Multiple Intelligences. MA thesis, Saint Xavier University and Skylight Professional Development Field-based Master's Program.

[36] Gentry, M., \& Owen, S. V. (1999). An investigation of total school flexible cluster grouping on identification, achievement, and classroom practices. Gifted Child Quarterly, 43, 224-243

[37] Goodman, K. S. (1990). Language and Thinking in School: A Whole Language Curriculum. New York: R.C. Owen Publishers

[38] Graham et. Al. 2015. 3 Differentiated Instruction. Retrieved from: https://education.alberta.ca/instructionalsupports/diffe rentiation/

[39] Heacox, D. (2001). Differentiating instruction in the regular classroom: How to reach and teach all learners, grades 3-12. Minneapolis, MN: Free Spirit Publishing.

Heidari, F., \& Khorasaniha, N. (2013). Delving into the Relationship between LOC, MI, and Reading Proficiency. Journal of Language Teaching and Research, 4(1). pp. 89-96.

[41] Issa, A. O., Aliyu, M. B., Akangbe, R. B. \& Adedeji, A. F. (2012) Reading Interest and Habits of the Federal Polytechnic Students. International Journal of Learning \& Development.Vol.2, No.1, pp 470-486.

[42] Kulik, J. A. (1992). An analysis of the research on ability grouping: Historical and contemporary perspectives (RBDM 9204). Storrs: University of Connecticut, The National Research Center on the Gifted and Talented

[43] Kamarulzaman, M., Azman, H., Zahidi, A. (2017). Differentiated Instruction Strategies in English Language Teaching for Gifted Students. Journal of Applied 
Environmental and Biological Sciences. 7(18) 78-90.

[44] Kumar, D., \& Bristor, V. (1999). Integrating Science and language arts through technology-based macrocontexts. Educational Review, 51(1), 41-53.

[45] Levande, D. (1999). Gifted readers and reading instruction. CAGCommunicator, 30, 19-20, 41-42.

[46] Linn-Cohen, R. \& Hertzog, N. (2007). Unlocking the GATE to differentiation: A qualitative study of two self-contained gifted classes. Journal for the Education of the Gifted. 31, No. 2, pp. 227-259.

[47] Lerner, J. (2000). Learning Disabilities: Theory, Diagnosis and Teaching Strategies. 8th Edition. Boston: Houghton Mifflin Company

[48] Marzano, R. J. (2003). What Works in schools: Translating research into action. Alexandria, VA: Association for Supervision and Curriculum Development.

[49] Mule, K. 2014. Types and cause of reading difficulties affecting the reading of English Language: A case of grade 4 learners in selected schools in Ogong Circuit Namibia. Retrieved from: http://repository.unam.edu.na/bitstream/han dle/11070/851/Mule2014.pdf?sequence $=1$

[50] Marzano, R. J., Norford, J. S., Paynter, D. E., Pickering, D. J., \&Gaddy, B. B. (2001). A handbook for classroom nstruction that works. Alexandria, VA: Association for Supervision and Curriculum Development.

[51] Marzano, R. J., Pickering, D., \& Pollock, J. E. (2001). Classroom instruction that works: Research-based strategies for increasing student achievement. Alexandria, VA: Association for Supervision and Curriculum Development.

[52] Motallebzadeh, K., \& Manouchehri, M. (2008). On the Relationship between Multiple Intelligences and Reading Comprehension gain on IELTS. SID Journal, 42(2), pp. 135-140.

[53] Morgan, H. (2014). Maximizing student success with differentiated learning. The Clearing House: A Journal of Educational Strategies, Issues and Ideas, 87(1), 34-38. doi:10.1080/00098655.2013.832130

[54] Margolese SK, Kline RB. (1999). Prediction of basic reading skills among young children with diverse linguistic backgrounds. Can J Behav Sci 1999;31:209Y16.

[55] Nyarko, K. Kugbey, N. Kofi, C.C. Cole, Y. Adentwi, K. (2018). English Reading Proficiency and Academic Performance Among Lower Primary School Children in Ghana. $\quad$ DOI: $\quad 10.1177 / 2158244018797019$ journals.sagepub.com/home/sgo

[56] Ocampo, D. 2018. Effectiveness of Differentiated Instruction in the Reading Comprehension Level of Grade-11 Senior High School Students. Asia Pacific Journal of Multidisciplinary Research.

[57] Ogbodo, R.O. (2010) Effective Study Habits in Educational Sector: Counseling Implications. Edo Journal of Counseling, Vol.3, No.2.pp. 1-11

[58] Owolabi, T., \& Okebukola, F. (2009). Improving the reading ability of science students through study groups and multiple intelligences. US-China Education Review, 6(2). pp. 38-43.

[59] Palani, K. K. (2012) Promising Reading Habits and Creating
Literate Social. International Reference Research Journal Vol. III Issue 2(1) pp 91

[60] Pozas, M., Letzel, V., \& Schneider, C. (2019). Teachers and differentiated instruction: exploring differentiation practices to address student diversity. Journal of Research in Special Educational Needs. doi:10.1111/1471-3802.12481.

[61] Rogers, K. M. A. (2009). A preliminary investigation and analysis of student learning style preferences in further and higher education. Journal of Further and Higher Education, 33 (1), 13-21.

[62] Rogers, K. B. (1991). The relationship of grouping practices to the education of the gifted and talented learner (RBDM9102). Storrs: University of Connecticut, The National Research Center on the Gifted and Talented.

[63] Razmjoo, S. A. (2008). On the relationship between multiple intelligences and language success. The Reading Matrix, 8(2), pp. 155-174.

[64] Shaughnessy, M. F. (1998). An Interview with Rita Dunn about learning styles. The Clearing House, 71 (3), 141-145.

[65] Shearer, B. (2004). Multiple intelligences theory after 20 years. Teachers college record, 106, 2-16. Retrieved March 6, 2008, from EBSCO Host Database.

[66] Shepard, J. S. (2004). Multiple ways of knowing: fostering resiliency through providing opportunities for participating in learning, Reclaiming children and youth, 12, 210- 216. Retrieved March 6, 2008, from EBSCO Host Database.

[67] Singh, Y. G. (2011) Academic Achievement and Study Habits of Higher Secondary Students. International Referred Research Journal 3 (27) pp. 2

[68] Sari, L. (2017). Improving reading comprehension through directed reading thinking activity (DRTA) strategy for the eight grade students of SMP, Nigeria 17 medan in the academic year 2016-2017.. Masters thesis p.1-70

[69] Santi, K. L., Francis, D. J., Currie, D., \& Wang, Q. (2015). Visual-motor integration skills: accuracy of predicting reading. Optometry and vision science: official publication of the American Academy of Optometry, 92(2), 217-226. https://doi.org/10.1097/OPX.0000000000000473

[70] Shields, P. M. and Rangarajan, N. (2013). A playbook for research methods: Integrating conceptual frameworks and project management. Stillwater, OK: New Forums Press. pp. $109-158$

[71] Simmons, Rachel M., "The Impact of Differentiated Instruction on Student Reading Level Throughout the Response to Intervention Model" (2015). Education Masters. Paper 310

[72] Sousa \& Tomlinson. 2011. Differentiating Instruction for Advanced Learners in the Mixed-Ability Middle classroom. Reston,VA:Eric Clearinghouse on Handicapped and Gifted Children.

[73] Thousand, J. S., Villa, R. A., \&Nevin, A. I. (2007). Differentiating instruction: Collaborative planning and teaching for universally designed learning. Thousand Oaks, CA: Corwin Press.

[74] Tomlinson, C. A., \& Eidson, C. C. (2003). Differentiation in practice: A resource guide for differentiating curriculum, 
grades K-5. Alexandria, VA: Association for Supervision and Curriculum Development.

[75] Tomlinson, C. A., \& McTighe, J. (2006). Integrating differentiated instruction and understanding by design. Alexandria, VA: Association for the Supervision and Curriculum Development

[76] Tulbure, C. (2011). Differentiated Instruction for Pre-service Teachers: An Experimental Investigation. Procedia - Social and Behavioral Sciences, 30, 448-452 doi:10.1016/j.sbspro. 2011.10.088

[77] Yigiter, K. Saricoban, A. \& Gurses, T. et. al. (2005). Reading strategies employed by ELT learners at the advanced level. The Reading Matrix, 5, (1)

[78] Yahsee, A. (2013). The reading difficulties in English and how to deal with them as perceived by teachers an students in Nablus District. An-Najah National University Faculty of Graduate Studies.

[79] Yabes, L. (2016). Reading performance of the Grade III pupils in Sinait District. Unpublished master's thesis, University of Northern Philippines, Vigan City.

[80] Tieso, C. L. (2002). The effects of grouping and curricular practices on intermediate students' math achievement (RM
02154). Storrs: University of Connecticut, The National Research Center on the Gifted and Talented.

[81] Turkeltaub, P.E., Garreau, L., Flowers, D.L., Zeffiro, T.A., and Eden, G.F. (2003). Development of neural mechanisms forreading. Nat. Neurosci.6, 767-773.

[82] Vygotsky, L.2010. Interaction between Learning and Development: Mind and Society. Cambridge. MA: Harvard University. Print.

[83] Voss, J., \& Silfies, L. (1996). Learning from history text: The interaction of knowledge and comprehension skill with text structure. Cognition and Instruction, 14, 45-68.

[84] Viadero, D. (2003). Staying Power. Education Week, 22, 32-34. Retrieved March 6, 2008, from Academic Search Premier Database.

[85] Vaughn, S., Linan-Thompson, S., Kouzekanani, K., Bryant, z D. P., Dickson, S., \& Blozis, S. A. (2003). Reading nstruction grouping for students with reading difficulties. Remedial and Special Education, 4(5),301-31

[86] Zerei, A. 2014. Multiple intelligences as predictors of reading comprehension and vocabulary knowledge. Indonesian Journal of Applied Linguistics, Vol. 4 No. 1, pp 22.23. 10.17509/ijal.v4i1.598 